\title{
The Vat Exemption for health care: EU Law and its impact on Swedish law*
}

DOI 10.1515/ntaxj-2015-0010

Received Oct 30, 2015; accepted Dec 18, 2015

\begin{abstract}
The general rule in EU law is that value-added tax (VAT) is to be levied on all goods and services. There are a number of exceptions, however, one of which applies to certain medical services. This paper examines the legal basis for tax exemptions in EU VAT law and in Swedish law, with particular attention to the extent to which the rapidly growing private health-care sector is covered by these tax exemptions.
\end{abstract}

Keywords: VAT; EU tax law; health care; medical care; Swedish VAT law

\section{Introduction}

\subsection{General}

According to the Swedish trade organization, Varrdföretagarna, employee numbers in the private health-care sector increased by more than 25,000 between 2008 and 2011 to 117,000. In 2011, the revenue of private health-care companies was 85 billion SEK and dividends amounted to 2.2 billion SEK. Of the aggregate net profit of 4.6 billion SEK, almost 2.4 billion SEK was reinvested in companies (Vårdföretagarna (2015)).

The importance of the distinction between taxable and exempt health services has increased in recent years, due mainly to the pace of privatization. This paper is based on the results of a study previously outlined in a monograph (Påhlsson (2015)).

Robert Påhlsson: Professor of Tax Law, School of Business, Economics and Law, University of Gothenburg, Sweden; Email: robert.pahlsson@law.gu.se

* This paper is part of a research project financed by the FORTE research council. My thanks go to Associate Professor Pernilla Rendahl for her valuable comments.
Medical care is one of the many exemptions in Article (Art.) 132.1 of the value-added tax (VAT) Directive, justified on socioeconomic grounds. ${ }^{1}$ This exemption was introduced in the 1970s, when most exempt services were almost exclusively delivered by public authorities and other public bodies. Historical accounts can be found in the tax literature (e.g., Henkow (2008); Rasmussen (2013)). Deregulation and privatization have significantly altered these conditions.

The Commission has initiated a discussion that may result in substantial proposals for change within the next few years. It also published a "consultation" (European Commission $(2011,2010)$ ), which resulted in a great deal of activity, not least in Sweden (Confederation of Swedish Enterprise (2015)).

There has been significant research in this area, including Rasmussen's (2013) thesis. In addition, a number of articles have treated the exceptions in Art. 132.1b and c of the VAT Directive (e.g., Agrell and Ericsson (2008); de la Feria (2010); Hölzer (2010); Janssen (2008); Lundström (2004); Niedermair (2006); Nieskens (2006); Novak-Stief (1999); Swinkels (2005)) and examined the other exceptions in Art. 132.1 (e.g., Henkow (2008); Hultqvist (1998); Jepsen (2010); Jespersen (2011)).

\subsection{The purpose of the study}

The purpose of this paper is to examine the definition of the VAT exemption for medical care in EU law and in Swedish domestic law. Several specific issues under consideration are worthy of mention. What are the scopes and delimitations of the medical-care concepts used in the Directive and in Swedish tax law? Which private actors are covered by the tax exemption? What scope does the direc-

1 See heading to Section IX, Chapter 2 of Council Directive 2006/112 / EC ("the VAT Directive") and http://europa.eu/legislation_ summaries/taxation/131057_sv.htm Accessed 8 October 2015. The European Court of Justice (ECJ) has repeatedly mentioned the purpose of the exception. See, for example, C-307/01 ECLI:EU:C:2003:627 d'Ambrumenil, para. 39, which refers to "objective of reducing the cost of health care and making it more accessible to individuals". 
tive leave the national legislatures, and how has this flexibility been used? Is the Swedish implementation consistent and comprehensive, or can it be criticized in any way?

This paper is limited to the exceptions for medical services expressed in Art. 132.1 points b and c of the VAT Directive. Thus the programmatic rule in Art. 131, which applies to all the exceptions, will not be dealt with specifically nor will the general exemption for public bodies in Art. 13, which has been treated by others (e.g., Aujean et al. (1999); de la Feria (2009); Henkow (2013); Rasmussen (2013)). This paper does not treat the specific provisions related to the supply of human organs, blood, or milk ${ }^{2}$ or the special provision on tax exemption for medical transportation $^{3}$ nor will the exception for the dental area or the specific provisions regarding cooperation between certain independent groups (Rasmussen (2013) $)^{4}$.

\subsection{The exemption manifests a fundamental conflict of interest}

It should be noted initially that the VAT exemption need not be perceived as positive for a trader. On the contrary, when it comes to the health-care sector, tax-free status is often described as negative, for at least three reasons.

Swedish commercial activities that are exempted from VAT can deduct the input tax on acquisitions for their businesses for income tax purposes only ${ }^{5}$. There is no deductibility for them within the VAT system. Public healthcare providers covered by the tax exemption do not charge VAT to their customers either, nor do they deduct the input tax on acquisitions. Public health-care providers do have the right to compensation, however, through a special system $^{6}$. The purpose of this arrangement is for VAT not to be a cost to the municipalities, on the assumption that the tax would not affect the municipalities' decisions to provide services in-house or by procurement from private contractors ${ }^{7}$. Consequently, there is no competition neutrality

2 Sec. IX Ch. 2 Art. $132.1 \mathrm{~d}$ of the VAT Directive.

3 Sec. IX Ch. 2 Art. $132.1 \mathrm{~g}$ of the VAT Directive.

4 Sec. IX Ch. 2 Art. 132.1 e and $f$ of the VAT Directive.

5 See the Swedish Inkomstskattelagen (IL) (Income Tax Act) Ch. 16 Art. 16 (Swed.).

6 See the Act on (2005:807) Compensation for Certain Value-added Tax for Local Governments (Swed.).

7 See, for example, the information from Skatteverket (SKV, the Swedish tax administration), available at http://www. skatteverket.se/foretagorganisationer/moms/momsforstatkommun/ momsersattningtillkommuner.4.18e1b10334ebe8bc80005490.html (Swed., Accessed 8 October 2015). between private and public health-care providers. Private clinics that deliver tax-exempt services have no right to deduct input tax; therefore, they do not have access to a system of compensation of the kind that applies to publicly owned counterparts.

Moreover, the VAT system holds a strong incentive for private entrepreneurs, who have both taxable and taxexempt businesses, to attribute as much of their costs as possible to the taxable portion, in order for deductions to be obtained ${ }^{8}$. This incentive is probably one reason why the number of legal cases concerning demarcation issues is relatively large.

Although the private health-care provider may want to be included in the taxable sector, it should be noted that consumer interest is just the opposite. It is consumers who end up carrying the VAT, and the purpose of the medicalcare exemption is to make health care more accessible ${ }^{9}$ for them.

The conclusion is that consumers and privately organized medical-care producers have conflicting interests. In addition, what is best for the economy is not necessarily best for the individual, of course. The conflicts of interest can be multiple and complex.

Furthermore, tax exemption for health services is in fundamental opposition to neutrality considerations. As noted in Section 1.1, the tax exemption is motivated by a desire that the costs for the final consumer should be kept particularly low in a field that represents basic human needs. These interests are fundamentally incompatible, and the demarcation between them must necessarily reflect a compromise. This issue must be handled with consistency and uniformity, both for care entrepreneurs and for the consumers who are the ultimate bearers of the tax burden.

8 It is necessary to distinguish between mixed activity and mixed supplies. With mixed business activities, deduction is allowed only for the portion of VAT corresponding to the use of the VAT-liable business. For joint acquisitions that cannot be allocated to any of the activities, the allocation is based on an appropriate basis. For mixed supply, either a sharing principle or a unity principle applies. The sharing principle means that each part of a mixed transaction is treated separately for VAT purposes. The unity approach means that a transaction comprising two or more parts should be considered as a single unit for VAT purposes. See Case C-349/96 ECLI:EU:C:1999:93 Card Protection Plan para. 29-31.

9 See Footnote 1. Theories about the extent to which differentiated tax can benefit industries and economically weaker groups are numerous and, for reasons of space, cannot be elaborated upon here. See, for example, Statens Offentliga Utredningar (SOU) 1997: 17, Annex 1, p. 15 ff. Also SOU 2002: 47, especially pp. 24-25 and 238-240 and SOU 2006: 90 p. 17-22 (Governmental inquiries, Swed.). 


\subsection{Outline}

The outline of the rest of this paper is as follows. Initially, the rules in the Directive are accounted for. Second, relevant case law of the European Court of Justice (ECJ) is analyzed, and an analysis of relevant ECJ case law is presented. The last part of the paper accounts for the Swedish implementation of the medical-care exemption. It also contains an analysis of its compatibility with EU law.

\section{Tax-free medical care under the VAT Directive}

\subsection{Introduction}

The section includes an initial inventory of the constituent elements of the Directive's Art. $132.1 \mathrm{~b}$ and c, in which the scope of the medical-care exception is defined. Subsequently, the identified prerequisites form the basis for the disposition of Sections 3 and 4, where I examine the ECJ's practice in this area and the Swedish implementation.

\subsection{Tax-exempt medical transactions under the VAT Directive}

\subsubsection{The exemption of medical care under Art. 132.1 b}

Art. 132.1 of the VAT Directive contains the fundamental rule for exempting transactions related to medical care. It must be particularly noted that the wording of the exemption for health care went through minor changes in connection with the adoption of Directive 2006/112/EC. The ECJ has held in the most general terms that Art. $132.1 \mathrm{~b}$ and c shall be interpreted in the same way as its predecessors, Art. 13 A.1 b and c of the Sixth Directive, and that the case law concerning the latter provisions is therefore relevant to the interpretation of the new versions. ${ }^{10}$ Point $b$ of Art. 132.1 delimits tax exemption in the following way:

(b) hospital and medical care and closely related activities undertaken by bodies governed by public law or, under social conditions comparable with

10 See case C-86/09 ECLI:EU:C:2010:334 Future Health Technologies para. 26-27. See, in addition, motivations No. 1 and 3 of the VAT Directive 2006/112/EG, referred to by the Court, and from which may be concluded that the new directive does not aim to change the scope of the Sixth Directive. those applicable to bodies governed by private law, by hospitals, centres for medical treatment or diagnosis and other duly recognized establishments of a similar nature ${ }^{11}$;

The Directive holds no definitions of the concepts used in Art. $132.1 \mathrm{~b}$ and c. Thus, their scope must be specified in case law. Consequently, the meaning of expressions such as medical care and closely related activities have been subjected to analysis by the ECJ in a number of cases that will be accounted for in the following sections.

Wording such as under social conditions comparable and other duly recognized establishments of a similar nature implicates a de facto delegation back to the member states of legislative power. This circumstance, too, is analyzed in Section 3.7.4.

\subsubsection{The special delegation rule in Art. 133}

A specific, detailed, and wordy clarification of the delegation to the Member States is made in the Directive's Title IX, Chapter 2, Art. 133. The implication is that Member States decide in principle which private legal entities shall enjoy the same tax exemption as public health-care providers. Please note that Art. 133 covers only the tax exemption provided for in Art. $132.1 \mathrm{~b}$, and not medical care outside the hospital sector, which is tax exempt under Art. 132.1 c.

Although relatively complex, the criteria in Art. 133 can be summarized into four categories: profit bans, voluntary work, price control, and competition harmfulness. Further investigation will show whether the ECJ has, in some respect, defined the framework for the delegation provided for in Art. 133.

It is not necessary for Member States to make use of the restrictions offered by Art. 133. The Swedish government that took office after the 2014 election has foretold profit restrictions on privately owned, publicly financed medical care in the coming years. Such restrictions may be combined with special Swedish VAT rules based on Art. 133 of the VAT Directive.

Given the dominant position of the neutrality principle within the VAT field, Art. 133 can be easily explained. It goes without saying that the organizations operating on

11 According to the special provision of Art. $132.1 \mathrm{k}$, hospital treatment provided by religious organizations is tax exempt when the provision is aimed at pastoral care. This rule, which is not discussed further in this work, should be viewed in the light of the general rule in Art. $132.1 \mathrm{~b}$, which covers only supplies governed by public law or by other duly recognized establishments of a similar nature. 
a market but are subjected to profit bans or price controls can constitute a challenge to competitive neutrality. In this context, Art. 133 serves as a reminder that neutrality is not the only interest that manifests itself in the field of medical care. Competition neutrality must endure competition (!) from the social reasons that are indeed the rationale for VAT exemption for medical services.

\subsubsection{The general clause in Art. 134}

The pursuit of neutrality pervades the entire field of VAT law. With respect to the obvious strain between the neutrality interest and reasons for the health-care tax exemption, Art. 134 must also be considered. This provision appears to be a general clause, emphasizing the caution with which the definition of the tax-free area should be chosen. It reads as follows:

The supply of goods or services shall not be granted exemption, as provided for in points (b), (g), (h), (i), (l), (m), and (n) of Article 132 (1), in the following cases:

a) where the supply is not essential to the transactions exempted;

b) where the basic purpose of the supply is to obtain additional income for the body in question through transactions which are in direct competition with those of commercial enterprises subject to VAT.

Art. 134 does not aim at restricting the scope of the tax exemptions per se. Rather, the provision targets those transactions that are related to tax-free transactions but that cannot be considered indispensable for them. As an example, supplies for comfort and convenience, such as hospital issue of tissues and cotton balls, have not been deemed strictly necessary to achieve the purpose of a tax exemption for medical care (Westberg (2009)) $)^{12}$.

The wording of point $b$ is cryptic and could mean a variety of things. It should likely be read as a real general clause, applicable to all transactions covered by the articles mentioned. Rasmussen (2013) noted that the ECJ interprets Art. 134 in a general way, which means that cases treating other fields where the provision has been applied may have relevance to the health area. It should be noted that the clarification of the scope mentions Art. $132.1 \mathrm{~b}$, but not Art. 132.1 c. The effective and reasonable way of reading the provision is to allow it to rule out a proportioning

12 See, for example, case C-394/04 and C395/04 ECLI:EU:C:2005:734 Ygeia para. 25-26 and 29. of the mixed expenses if the activities in question are the results of competition in nonexempt areas.

\subsubsection{The exemption for medical care under Art. 132.1 c}

Point c of Art. 132.1 of the VAT Directive provides “(c) the provision of medical care in the exercise of the medical and paramedical professions as defined by the Member State concerned"13. As with the concept of medical care mentioned in Art. $132.1 \mathrm{~b}$, there is no definition of the concept of medical care under point c. Unlike point b, point c makes no explicit distinction between care provided by public or private bodies. Rather, it refers only to medical and paramedical professions as defined by the Member State concerned.

The wording implies that here, as indeed in the last paragraph of Art. 132.1 point b, the EU delegates the definition of medical and paramedical professions to the Member States ${ }^{14}$. It is up to the national legislators to define the professional categories to be covered by the tax exemption. Further investigation will show the extent to which the ECJ's practice restricts this right.

\section{Tax-free medical care under the case law of the European Court of Justice (EC))}

\subsection{Introduction}

The ECJ has treated the exceptions in Art. 132.1 points $\mathrm{b}$ and $\mathrm{c}$ on several occasions; 15 cases emerge as key ${ }^{15}$. Two of the oldest were infringement proceedings against

13 The term "paramedical" denotes the part of health care working with treatments, such as physiotherapy, that are not considered strictly medical.

14 Compare the expression "other duly recognised establishments of a similar nature” (Sw. andra i vederbörlig ordning erkända inrättningar av liknande art) in Art. $132.1 \mathrm{~b}$.

15 The paper also carries references to other cases that are relevant to the study. The 15 most important decisions by the ECJ in this field are cases C-353/85 ECLI:EU:C:1988:82 Commission v United Kingdom, C-384/98 ECLI:EU:C:2000:444 D., C-76/99 ECLI:EU:C:2001:12 Kommissionen mot Frankrike, C-141/00 ECLI:EU:C:2002:473 Kugler, C-45/01 ECLI:EU:C:2003:595 Dornier, C-212/01 ECLI:EU:C:2003:625 Unterpertinger, C-307/01 d'Ambrumenil, joined cases C-394/04 Ygeia och C395/04 Ypourgos, joined cases C-443/04 ECLI:EU:C:2006:257 Solleveld och C-444/04 van Eijnsbergen, C-106/05 ECLI:EU:C:2006:380 L.u.P., C-262/08 ECLI:EU:C:2010:328 CopyGene, C-86/09 Future Health, C- 
the United Kingdom and France ${ }^{16}$. In the case against the United Kingdom, the Commission argued that the British national law extended the exemption for medical care too far and that VAT in France was being levied on transactions that should have been excluded.

The other 13 cases are preliminary rulings in which the question was whether a private individual or a company should pay VAT. VAT on supplies from private entrepreneurs was the issue in 11 of the cases-specifically cases of companies or self-employed private individuals. In nine of these cases, the entrepreneurs had been denied VAT exemption under domestic law but argued that their supplies should be tax free. In two of the cases, the situation was the opposite: The entrepreneurs believed that their supplies should be subject to VAT.

\subsection{General starting points for the ECJ's interpretation of Art. 132.1 b and c}

The Court uses four principal starting points when it interprets Art. $132.1 \mathrm{~b}$ and c: strictness, autonomous concepts, efficiency, and neutrality. The first three are discussed in this section. The neutrality aspect takes up a little more space and is treated as a separate item in the following sections.

The ECJ emphasizes with great clarity and in a number of cases that the VAT exemptions for health-care services "are to be interpreted strictly since they constitute exceptions to the general principle that VAT is to be levied on all supplies of services for consideration by a taxable person". The principle of neutrality must be considered, while giving the concepts used in the Directive's exemption a content that responds to their purpose ${ }^{17}$.

The ECJ's strictness in this matter is neutralized to some extent by its statements about the importance of exceptions interpreted in accordance with their purpose. Admittedly, the Court emphasizes the purpose of the exemption: that only well-defined phenomena should be exempted and that the public interest is not in itself a factor

156/09 ECLI:EU:C:2010:695 Verigen, C-91/12 ECLI:EU:C:2013:198 PFC Clinic and C-366/12 ECLI:EU:C:2014:143 Klinikum Dortmund.

16 C-353/85 Commission $v$ United Kingdom and C-76/99 Commission $v$ French Republic.

17 C-106/05 L.u.P. para. 24. See also, for example, C-307/01 d'Ambrumenil para. 52 and C-212/01 Unterpertinger para. 34. Possibly, this represents the ECJ's general view on VAT exemptions; see, for example, C-348/87 ECLI:EU:C:1989:246 Stichting Uitvoering financiele Acties (SUFA) para. 13, C-284/03 ECLI:EU:C:2004:730 Temco para. 17 and C-8/01 ECLI:EU:C:2003:621 Taksatorringen para. 62. in favor of tax exemption ${ }^{18}$. But it is also clear that the concepts used to define the scope of the tax exemption, such as activities closely related to medical care, should not be interpreted narrowly, because the use of this concept "is designed to ensure that the benefits flowing from such care are not hindered by the increased costs of providing it that would follow if it, or closely related activities, were subject to VAT" ${ }^{\prime 19}$.

Correspondingly, the Court clarifies in more general terms: "Thus, the requirement of strict interpretation does not mean that the terms used to specify the exemptions referred to in Article 132 should be construed in such a way as to deprive the exemptions of their intended effect..."20

The ECJ seems to hold that exemptions, but not the words that define the exceptions, should be strictly interpreted. There is no doubt that such statements, read together, imply a certain lack of intellectual precision. The ambiguity and contradiction in the statements weaken their strength as legal tools. The conclusion is that they (of course) must be kept in mind when analyzing case law, but that the statements of strictness and effectiveness cannot independently be of much help in further analysis. It is clear, however, that this type of statement can be beneficial for those who want to argue for a particular solution in a particular case.

The Court's position that the concepts are autonomous is more robust. "Those exemptions constitute independent concepts of Community law whose purpose is to avoid divergences in the application of the VAT system from one Member State to another" ${ }^{21}$. Thus, it must be concluded that the medical-care concept is to be applied uniformly throughout the $\mathrm{EU}^{22}$.

18 See, for example, C-307/01 d'Ambrumenil para. 54.

19 C-76/99 Commission v French Republic para. 23.

20 C-86/09 Future Health Technologies p. 30. Also C-45/01 Dornier para. 48. Corresponding views regarding other exemptions in, for example, C-445/05 ECLI:EU:C:2007:344 Haderer para. 18, C407/07 ECLI:EU:C:2008:713 Stichting Centraal para. 30 and C-357/07 ECLI:EU:C:2009:248 TNT Post UK para. 31.

21 See, for example, C-307/01 d'Ambrumenil para. 52, C-212/01 Unterpertinger para. 34 ad C-76/99 Commission v French Republic para. 21. For corresponding views on the exemption for financial services see 235/85 Commission $v$ Kingdom of the Netherlands para. 18 and 347/87 Stichting Uitvoering Financiele Acties para. 11.

22 As will be shown below, this conclusion is valid also for the concept closely related in Art. $132.1 \mathrm{~b}$. 


\subsection{General on the neutrality in EU VAT law}

It certainly seems to be a truism that neutrality aspects must always be considered in the interpretation and application of EU VAT law. Indeed, neutrality is a general norm in this field of law, which is underlined by Article 134.

There has been extensive discussion around the concept of neutrality and its position in VAT law in tax literature (e.g., Alhager (2001); Eskildsen (2012); Henkow (2008); Melz (1990); Ramsdahl Jensen (2004); Rendahl (2009); Sonnerby (2010); Stensgaard (2004); Theile (1995); Westberg (1994); Öberg (2001)). For this reason, and because of limited space, of course, I do not address the question of the general systematical position of neutrality in this paper. I do, however, account for the ECJ's position on neutrality as a concrete tool for interpreting Art. $132.1 \mathrm{~b}$ and c specifically.

\subsection{Neutrality as a tool in the ECJ's interpretation of the medical-care exemption}

The most common type of ECJ reference to neutrality can be characterized as a general statement, which is also frequent in terms of the need for strictness. These general statements are often made in conjunction with other basic interests-the purpose of the tax exemption, for example, "However, the interpretation of the terms used in that provision must be consistent with the objectives pursued by those exemptions and comply with the requirements of the principle of fiscal neutrality inherent in the common system of VAT"23.

This sort of recurring reference shows that the Court would emphasize the significance of neutrality, not only as a building block of the VAT system but also as a concrete aid to the interpretation of the exemption. In the following two sections, I discuss this issue with regard to the entrepreneur's legal form and type of industry, activity, and location.

\subsection{Neutrality with respect to legal form}

Neutrality with respect to legal form in the context of interpreting the VAT exemptions has received some attention in literature (e.g., Sonnerby (2010)), and the ECJ has treated this issue with reference to Art. $132.1 \mathrm{~b}$ and $\mathrm{c}$ in a number of

23 C-45/01 Dornier para. 42. cases $^{24}$. The Court's statements allow for three interrelated key conclusions.

First, different legal form must be given neutral treatment when the rules are interpreted (Rasmussen (2013); Westberg (2009) $)^{25}$. Second, it takes explicit support in the Directive for a deviation from competition neutrality, which is a basic principle of EU VAT law. This aspect of neutrality applies also to the application of the medicalcare exception. In other words, the exemption is applicable within the framework of the principle of neutrality such as this principle is normally interpreted by the regarding exemptions (Rendahl (2009)). Third, one could also conclude that the delegation de facto of legislative power in Art. $132.1 \mathrm{~b}$ and $\mathrm{c}$ to national legislators does not include different treatment of different types of companies that perform the same activities. Member States may not take advantage of the delegation in a way that separates the taxable from the tax-exempt area only by using the legal form. These conclusions may be viewed as tentative, however, because they must be examined in the light of the other case law regarding the medical-care exemption, which is treated in the following sections.

\subsection{Neutrality with respect to type of industry, activity, and location}

The ECJ has treated this issue with reference to Art. $132.1 \mathrm{~b}$ and $c$ in a number of cases ${ }^{26}$. The Court's statements lead to the conclusion that neutrality prevails within the same industry when interpreting the terms used in the Directive's exemption regarding medical care. This means that the delimitation of phenomena closely related to medical care (Art. $132.1 \mathrm{~b}$ ) must be made with some strictness, so that competition between producers of these services is not disrupted. This applies, for example, to the delivery of food and accommodation for relatives who are given the opportunity of staying with hospital patients.

Moreover, this restrictiveness appears to be a main rule for the application of the exemption. The restrictiveness is justified on the grounds that the rules are exceptions to the general principle that VAT is to be levied on

24 See C-141/00 Kugler para. 26-31, C-45/01 Dornier para. 18-21 and C-498/03 ECLI:EU:C:2005:322 Kingscrest. See also the Court's statements in C-106/05 L.u.P. para.50 and C-262/08 CopyGene para. 57 and 61.

25 See also C-216/97 ECLI:EU:C:1999:390 Gregg and Gregg.

26 See C-394/04 and C-395/04 Ygeia para. 24-31, C-443/04 and C444/04 Solleveld para. 30-37 and C-106/05 L.u.P. para. 24-32. 
services $^{27}$. This approach contrasts with the ECJ's interpretation of the central term, medical care, which according to the Court, need not be interpreted strictly ${ }^{28}$, because the purpose of the exemption is to reduce health-care costs. The restrictiveness does not apply primarily to the exemption's central area but to its border areas. The desire for neutrality between transactions within various types of industries reinforces the requirement for restrictive interpretation. In addition, the principle of fiscal neutrality must be respected when Member States exercise the delegation provisions. There are, in principle, two delegation provisions embedded in the exemption for medical care. Art. $132.1 \mathrm{~b}$ speaks of "centres for medical treatment or diagnosis and other duly recognised establishments of a similar nature”. For medical care outside of hospitals, Art. 132.1 c identifies "the medical and paramedical professions as defined by the Member State concerned".

It seems to follow from the ECJ's practice that the Member States' room for maneuvering covers both occupational categories and types of activities, including the detailed description of these categories. When Member States exercise their option to include or exclude various categories, nonconformities must be based on objective differences-education and skills, for example. Indeed, the differences must be objectively justified. In this way, the court handles the contradiction that could otherwise arise between the neutrality requirement and the national maneuvering space.

Finally, the principle of fiscal neutrality must be observed with regard to the location of the services performed. It should be noted that the ECJ requires that service providers with the same education should otherwise be treated differently. This ruling suggests that the requirement of neutrality resulting from comparable professional qualities is applicable not only to the definition of professionals under Art. $132.1 \mathrm{c}$ but also in defining the other institutions of similar nature in Art. $132.1 \mathrm{~b}^{29}$.

\subsection{The key criteria of the medical-care exemption}

\subsubsection{Introduction}

The ECJ's practice includes significant clarification of the following prerequisites in Art. 132.1 points $\mathrm{b}$ and c. Case

27 See, for example, C-45/01 Dornier para.42.

28 See C-45/01 Dornier para. 48.

29 See C-106/05 L.u.P. law, therefore, allows for an analysis of the following key criteria for tax exemption.

a) What is the Directive's scope of the medical-care concept under Art. $132.1 \mathrm{~b}$ ?

b) How are the closely related activities to such medical care defined?

c) Which are the duly recognized establishments of a similar nature that may deliver those services tax free?

d) What is the meaning of the concept of medical care under Art. $132.1 \mathrm{c}$ ?

e) Has the ECJ specified the Member States' room for maneuvering provided for by the delegation phrase medical and paramedical professions as defined by the Member State concerned?

\subsubsection{What is the Directive's scope of the medical-care concept under Art. $132.1 \mathrm{~b}$ ?}

In its earlier practice, the ECJ seems to have assumed that the health-care concepts, which now appear in Article $132.1 \mathrm{~b}$, mainly comprised public entities supplying care on a nonprofit basis ${ }^{30}$. Subsequently, it was held that supplies from a private law foundation could fulfill the sufficient medical purposes of the Directive ${ }^{31}$. For a number of years, it has been clear that ordinary companies, driven by profit, can provide such medical care as is covered by the exemption ${ }^{32}$

The ECJ has gradually established the principle of the therapeutic purpose, meaning medical care is defined as a services whose purpose is "the diagnosis, treatment and, in so far as possible, cure of diseases or health disorders" ${ }^{33}$. It must be stressed that this definition also includes preventive measures, specifically “....medical services effected for the purpose of protecting, including maintaining or restoring, human health..."34. The definition includes treatment of both body and mind.

Case law establishes the principle of the therapeutic purpose as a mandatory condition for medical care under Art. $132.1 \mathrm{~b}$. The Court's statements are clear and must be

\footnotetext{
30 See C-353/85 Commission v United Kingdom para. 32. 31 See C-45/01 Dornier.

32 A different issue is that Member States under Art. 133 have the option to impose restrictions.

33 C-45/01 Dornier para. 48. This is a recurring expression, see, for example, C-394/04 and C-395/04 Ygeia para. 24 and C-106/05 L.u.P. para. 27.

34 C-106/05 L.u.P. para. 29.
} 
interpreted $e$ contrario: If the supply of a service or a commodity is not within the targeted therapeutic purpose, it cannot constitute medical care. Any exemption must be justified by the prerequisite "closely related".

The Court's definition of medical care also leads to the conclusion that tax exemption does not depend on a diagnosis having been made, or even that a diagnosis will ever be made. It follows from case law, however, that "approved" prevention must have a certain connection in substance and in time with visits or treatment by medical or other therapeutic expertise. General measures that may be relevant to your health in the future are not included ${ }^{35}$.

Furthermore, it is the medical or other therapeutic expertise that determines whether a supply has the required therapeutic purpose ${ }^{36}$. This objective health concept does not prevent the patients' subjective perceptions of their needs from being significant, however (Rasmussen (2013)). It is not entirely clear how to draw the line here. On the one hand, patients' perceptions of the need for plastic surgery is generally not enough for it to be considered as having the required therapeutic purpose. It is clear, however, that an examination provided by a physician to someone with health concerns is indeed tax exempt.

In case C-91/12 PFC Clinic, the ECJ held that plastic surgery was tax exempt only if it fulfilled general criteria laid out in earlier case law and provided that the need was assessed by professionals. This question may be more complex than expected. Should the boundaries between aesthetics and medicine be subject to national variations, for example, formulated by the respective Member State's health authorities and expressed in terms of legislation other than tax law? Or should it be assumed that medical staff in casu decides on the definition of medical and aesthetic-related procedures?

The desire for uniformity suggests that national guidelines summarizing the current views on medicine should, at least to some extent, be allowed to govern individual assessments. The national health authorities could play a major role here, and legislation other than the tax law could indeed be consulted when the boundary between aesthetics and care is to be drawn in a specific case. The influence of national legislation can be convenient, therefore, but it should be recalled that this cannot be allowed

35 See cases C-262/08 CopyGene para. 36 and C-86/09 Future Health Technologies para. 36-40 and 43. In these cases, tax exemption was not allowed for services providing private stem cell banks through the collection, transportation, analysis, and storage of umbilical cord blood from newborn children.

36 See C-91/12 P FC Clinic para. 34-35. to erode the EU's concept of medical care. It is obvious that this issue incorporates a contradiction between practical and principal interests.

It would seem that the further one is from a medical "core business", the more important it is that someone with the necessary professional qualifications acknowledge the therapeutic objective. This observation emphasizes the fact that this issue must be the subject of evidence rather than a point of law ${ }^{37}$. Under Art. $132.1 \mathrm{~b}$, however, the staff who performs the actual health-care services does not have to be licensed separately ${ }^{38}$.

Finally, when it comes to mixed activities-activities that consist of both taxable and tax-free supplies-the same principles of allocation apply as regards other mixed operations. These rules are contained in the VAT Directive Art. 173-175. Their detailed content falls outside the scope of this paper.

\subsubsection{How are the closely related activities to medical care defined?}

It should be noted that the wording of Art. $132.1 \mathrm{~b}$ of the VAT Directive mentions activities closely related to medical care. The corresponding wording of the Sixth Directive was hospital and medical care and closely related activities ${ }^{39}$.

Several conclusions can be drawn from the ECJ's case law. The exemption of closely related transactions applies only to medical care under Art. $132.1 \mathrm{~b}$. There is no corresponding exemption provision applicable to medical care under Art. $132.1 \mathrm{c}$ : care that is performed outside institutions and other establishments of a similar kind-at home or in doctors' offices, for example ${ }^{40}$.

Furthermore, it is clear from case law that the prerequisite closely related can refer to both goods and services. Only small supplies of goods that cannot be distinguished from care are tax free, however-not medications, unless

37 Of course this does not apply without exception. Statutory rules on acknowledgment of certain persons or professions may have to be interpreted.

38 Please note that this applies to medical care under Art. 132.1 b. For care falling under Art. $132.1 \mathrm{c}$, a different assessment must be made. See Section 3.7.5.

39 The ECJ has made it clear that the older and younger provisions of the Directive should be interpreted in the same way and that the older practice still has relevance, see Art. 13 A1 b of Directive 77/388/EEG and C-86/09 Future Health Technologies para. 26-27 and p. 50.

40 See C-366/12 Klinikum Dortmund para. 32 and the older case C353/85 The Commission v United Kingdom, where the corresponding conclusion is drawn. 
they are absolutely necessary for the medical treatment itself, and cannot be separated from the medical treatment ${ }^{41}$. According to the ECJ, the administration of a cancer drug can possibly fulfill the demands, but the court declined to make this assessment in casu ${ }^{42}$. Another example could be bandages ${ }^{43}$.

As a prerequisite, a transaction must be subordinate to the primary health-care transaction for it to be deemed closely related to it. A service must be regarded as ancillary to a principal service if the customers do not ask for it specifically, but it is only a means to the enjoyment of the actual service supplied ${ }^{44}$ and is not a sufficient condition. Under Art. 134, the ancillary supply must be essential for principal health-care service in order to fulfill its purpose. Consequently, Art. $132.1 \mathrm{~b}$ must be read together with the necessity requirement in Art. 134.

Finally, a connection in time between the ancillary, closely related transaction and principal care is not necessary, in order for the tax exemption to apply to the former. The assessment must be made at the time of the transaction and be based on what people in relevant professional standing may know or reasonably assume at that time $\mathrm{e}^{45}$. This assumption can vary depending on the risks or illnesses that may cause concern.

\subsubsection{Which are the duly recognized establishments of $a$ similar nature mentioned in Art. $132.1 \mathrm{~b}$ ?}

This section examines the scope of the delegation rule in Art. 132.1 b, as specified in ECJ case law. The core question is the extent to which the ECJ has delegated to Member States the possibility of imposing conditions for the recog-

\footnotetext{
41 See C-366/12 Klinikum Dortmund para. 33-34.

42 C-366/12 Klinikum Dortmund para. 37. In Sweden, the supply of drugs is subject to the following special regulations. Under Ch. 3 Art. 23 §p. 2 of the VAT Act sales of drugs dispensed on prescription or sold to hospitals are tax exempt. The VAT Directive contains no exception equivalent to the Swedish derogation for pharmaceuticals. Under Annex XV, Section IX, para. 2 of the accession treaty between the European Union Member States and Sweden concerning Sweden's accession to the European Union; however, Sweden has the right, during a transitional period, to exempt the sale of pharmaceuticals to hospitals or on prescription. See also the Swedish case Högsta förvaltningsdomstolen (HFD, Supreme Administrative Court) RÅ 2003 ref. 29 (Swed.).

43 See C-366/12 Klinikum Dortmund para. 33.

44 See C-349/96 Card Protection Plan para. 30. Also C-45/01 Dornier para. 33. The Court elaborates further in C-394/04 and C-395/04 Ygeia para. 20-30.

45 See C-262/08 CopyGene para. 48.
}

nition of certain suppliers as a prerequisite for tax exemption for certain medical services.

Several conclusions can be drawn from the EC)'s practice. There are no formal requirements for the recognition referred to in the wording of Art. 132.1 b. Indeed, no explicit recognition of the suppliers covered by Art. $132.1 \mathrm{~b}$ is necessary. Rather, it is clear that recognition can be implied ${ }^{46}$.

It is in the hands of the Member States to decide on this recognition and its conditions. In practice, this means that Member States indirectly dispose of the medical concept applied outside the hospital sphere-at least to some extent. Admittedly, they do not decide on the very definition of medical care, but they do affect the scope of the definition by determining the subjects that gain access to it, meaning that the national room for maneuvering stretches slightly longer than one may initially imagine. It is hardly correct to say that the notion of medical care is an altogether autonomous concept of EU law.

It may be inferred, however, that two types of conditions are generally prohibited. First, it is not possible to curtail the medical-care concept under Art. 132.1 b by making it a condition for tax exemption that the transactions would have been tax exempt by virtue of Art. $132.1 \mathrm{c} \mathrm{had}$ they been performed by a member of the paramedical professions ${ }^{47}$. Second, neutrality and equality must be maintained, at least within the same Member State ${ }^{48}$. It seems to be a consequence of the delegation to the Member States that equal treatment need not be maintained between taxpayers in different Member States. This statement must be put to question, however. The freedom of movement as provided for by the TFEU may not be restricted without proper justification.

What type of condition, then, is permitted under the delegation provision in Art. $132.1 \mathrm{~b}$ ? It follows from case C-45/01 Dorner that it is permissible for Member States to make the tax exemption dependent on a degree of financing through social insurance. Moreover, it seems permissible to link the assessment to the existence of specific authorization ${ }^{49}$. Apart from this, the Court's statements are vague, which indeed seems reasonable, given that the issue of recognition and the conditions have been delegated to the Member States. The ECJ seems to maintain, however, that this self-determination should not rest only on equal treatment but should take into account the degree of public benefit to the taxable person.

\footnotetext{
46 See C-45/01 Dornier para. 64-67. 47 See C-45/01 Dornier para. 69-71. 48 See C-262/08 CopyGene para. 66. 49 See C-262/08 CopyGene, especially para. 57-61.
} 
With respect to this context, it may be concluded that Art.133 is not to be regarded as exhaustive. It is indeed possible to set other conditions for recognition than those found in the article. It may be recalled, however, that neither Art. 133 nor the delegation in Art. $132.1 \mathrm{~b}$ applies to such medical care referred to in Art. $132.1 \mathrm{c}$.

Finally, there is no support in either Art. $132.1 \mathrm{~b}$ or Art. 133 for the exclusion of private subjects from the scope of the exemption simply because they are organized under private law. As we have seen, however, specific conditions may be laid down for them. It should be borne in mind that the potentially most intrusive permissible restrictions in fact follow directly from the optional Art. 133. Of particular importance is the possibility of providing for profit bans and price control.

\subsubsection{What is the scope of the concept of medical care under Art. 132.1 c?}

It is clear from the ECJ's case law that the term "medical care" under Art. $132.1 \mathrm{~b}$ also covers any medical care referred to in Art. 132.1 C (previously Art. 13 A.1 c). It has also been held that the medical-care concept does not include any service provided in a hospital at whatever time but only those that can be subsumed under the specified therapeutic purpose.

This speaks in favor of the concepts of medical care under Art. $132.1 \mathrm{~b}$ and $\mathrm{c}$ being synonymous-that they denote the same supplies. The principal difference between them would then be the place of supply. Indeed, further analysis of case law seems to verify this conclusion. There are identical requirements for the therapeutic aim that is to be fulfilled ${ }^{50}$. The aim should be to make a diagnosis, provide care, and, wherever possible, cure diseases and health problems. As concluded in Section 3.7.2, the therapeutic purpose also includes prevention.

There are two factors that distinguish the concepts of medical care in Art. 132.1 b and c, respectively, the place of supply and the demands placed on the providers in order for their supplies to be covered by the exemption. In addition, the transactions closely related to medical care are tax free only under Art. $132.1 \mathrm{~b}$. Not surprisingly, this rule is interpreted by the ECJ to the effect that the corresponding extension cannot be applied in respect of medical care un-

50 See C-384/98 D para. 18, C-212/01 Unterpertinger para. 40-41 and C-45/01 Dornier para. 48. der Art. 132.1 $\mathrm{c}^{51}$. It would seem, therefore, that the scope for supplying goods tax free is narrower under Art. 132.1 c than under point $b$.

In the case of certificates, the Court has clarified the therapeutic purpose. The implication is that a contribution to a third party's decision making does not constitute medical care, unless the certificate aims at certifying that restrictions are required in order for a person to obtain permits, to exercise a certain activity. In contrast, regular medical examinations, even routine ones, fulfill the therapeutic purpose if the aim is to detect potential health problems. It is irrelevant whether the physician is acting for an employer or for the patient. It is the purpose of the action that is relevant ${ }^{52}$.

Under the ECJ's practice, the relevance of medical measures should be assessed by medical experts. The patient's own opinion is not decisive, a situation that creates a relatively objective health concept promoting both neutrality and equal treatment (Rasmussen (2013)). The ECJ itself can, of course, reexamine everyone else's assessment of the facts. Case law suggests that the interpretation of reality (facts) is restrictive, although the interpretation of the wording of the Directive does not need to be.

\subsubsection{Has the ECJ specified what is meant by medical and paramedical professions as defined by the Member State concerned in Art. $132.1 \mathrm{c}$ ?}

The wording of Art. $132.1 \mathrm{c}$ provides, as in the last paragraph of Art. 132.1 b, that a delegation to the Member States determines who should be covered by the tax exemption. The condition laid out in the Directive is that the persons represent the medical and paramedical professions.

It should be emphasized that the delegation comprises only the definition of the practitioners and not the treatment they will perform for the tax exemption to apply. The treatment characteristics have been studied previously and cover, among other things, a strict requirement for therapeutic purposes.

It follows from the ECJ's case law that the Member States dispose freely of the definitions of paramedical professions. Furthermore, they define the services that are to

51 See C-353/85 Commission v United Kingdom and C-366/12 Klinikum Dortmund. The Swedish version of the Directive uses different terms in Art. 132.1 b and c (sjukvård and sjukvårdande behandling). This inconsistency is confusing; the consistent terminology in the English version is preferable.

52 See C-307/01 d'Ambrumenil p. 61-67. 
be tax free for a certain type of professional. The margin for maneuvering, however, is circumscribed by an unconditional requirement of equal treatment and neutrality. This means that the legal form cannot be made decisive for distinguishing between taxable and tax-exempt supplies. This requirement is, in turn, based on a conception of a basic quality ${ }^{53}$.

Although the Member States' room for maneuvering is, therefore, subject to significant restrictions, a parallel can be drawn between the situation with regard to the definition of paramedical professions and recognized establishments of a similar nature under Art. $132.1 \mathrm{~b}$ that compare with hospitals. In both cases, the result of the delegation is that the Member States may indirectly influence the medical-care concept as such.

Regarding the requirements for personnel performing health-care services, there is a crucial difference between the tax exemptions under Art. $132.1 \mathrm{~b}$ and c. For the exemption under point $b$, it is immaterial whether the personnel performing the activity are formally qualified or not. Tax exemption based on point c, however, includes only the medical and paramedical professions as defined by the Member State concerned.

\section{Tax-exempt medical care under Swedish national law}

\subsection{General on tax-exempt medical care under the Swedish VAT Act}

The implementation in Swedish law of the exemption for medical care is placed in Chapter 3 Articles 4-5 of the VAT Act (Sw. Mervärdesskattelagen, SFS 1994:200). The relevant provisions read as follows ${ }^{54}$.

\section{Art. 4}

Exempt from tax are sales of services that constitute medical care, dental care, or social care and other kinds of services and goods supplied as part of the care.

The exemption also covers

- checks and analyzes of samples taken as part of medical or dental care, and

53 See C-443/04 and C-444/04 Solleveld, in particular para. 27, 29, 33, and 37.

54 My translation.
- the sale of dental technical products and services related to these products when the product or service is provided by dentists or dental technicians.

The exception does not apply to the sale of glasses or other visual aids, even if the goods are traded as part of the provision of medical care. The exception does not apply to the sale of goods when they are traded by pharmacists or dispensers. Regarding the sale of drugs dispensed on prescription or sold to hospitals, there are specific provisions in Art. 23 para. 2. The exception does not apply to the care of animals.

Art. 5

By medical care is meant measures for the medical prevention, investigation, or treatment of diseases, physical defects and injuries, and care at childbirth,

- if the measures are taken in a hospital or in any other institution run by the public; or, in private activity, at institutions for patient care; or

- if the measures are otherwise taken by someone with special identification to practice a profession in medical care.

Medical care also covers medical care transport performed by vehicles that are specifically established for such transportation. Medical care also covers medically induced foot care.

This regulatory design means that health care is generally exempt under Art. 4, regardless of whether it is conducted in public or in private. Subsequently, Art. 5 defines the concept of medical care in a way that involves some but not all private law subjects. Notably, the definition is a construction in Swedish national law and not only a representation of the Directive.

It must be remembered that the medical concept of the Directive is not subject to any delegation to the Member States. Their room for maneuvering is restricted to the designation of certain subjects. Yet Chapter 3 Art. 4 of the Swedish VAT Act provides a detailed and precise definition of the concept ${ }^{55}$. The explanation is that the medical-

55 There are many statements about the characteristics of the medical-care concept dating from before Sweden's accession to the EU. Of course, these statements cannot justify deviations today from concepts laid down by the ECJ. See, for example, proposition (prop.) 1989/90:111 p. 107 (Swed., Government bill). Subsequently, the Supreme Administrative Court has treated the concept in a number of cases. See, for example, Högsta förvaltningsdomstolen (HFD) (Supreme Administrative Court) RÅ 1996 ref. 74, RÅ 1997 not. 71, RÅ 
care concept in the old VAT Act that applied prior to Sweden's entry into the EU was simply transferred, essentially unchanged, to the new legislation. At that time-in1995the ECJ had not yet made all of the specifications of the medical-care concept.

\subsection{Questions to the Swedish legal sources}

In the following, I pose two fundamental questions to the Swedish material:

1. Is there sufficient support in Swedish national tax law to uphold EU law?

2. Does Swedish national law deviate in any respect from EU law?

These questions require a number of clarifications. The first issue is to determine whether the Swedish domestic law allows for the implementation of EU law in the way it requires. The question is based on the Directive, therefore, and is directed primarily at the Swedish VAT Act, which is the only binding source of national law. If the answer is yes-if the VAT Act allows for EU law to have its intended impact-no other Swedish sources of law need to be consulted. If the VAT is not sufficient for EU law to have the required impact, however, it must be examined to determine whether such an impact can still be the outcome by the conform interpretation of the law. Should this not be possible-because of the principle of legality, for examplebut the application of relevant EU law is to the benefit of the individual, the Directive will be applied directly on the principle of direct effect ${ }^{56}$. The ECJ has made it clear that the exemptions for medical care in Art. $132.1 \mathrm{~b}$ and $\mathrm{c}$ have direct effect, to the extent that they benefit taxpayers ${ }^{57}$.

If applying the rules of the Directive does not appear to be favorable to the taxpayer, however, the rules do not have direct effect. In that case, it is necessary to examine whether the Swedish VAT Act, with the help of other sources of law including the principles of interpretation of the law, can still be reconciled with EU law through interpretation.

Thus, while Question 1 (Is there sufficient support in Swedish national tax law to uphold EU law?) covers the possibility of a correct implementation of EU law in Swe-

2001 not. 40, RÅ 2003 ref. 5, RÅ 2007 ref. 88 and HFD 2011 not. 11 (Swed.).

56 An entrepreneur's falling under the scope of the VAT Directive may be regarded by the entrepreneur as positive or negative, depending on the circumstances.

57 See C-45/01 Dornier para. 81. den, Question 2 (Does Swedish national law deviate in any respect from EU law?) highlights the likelihood that this will be the case ${ }^{58}$.

\subsection{The key criteria of the medical-care exemption in Swedish law}

\subsubsection{The medical-care concept in the VAT Act}

As was shown in Section 4.1, for historical reasons, the Swedish VAT Act contains its own definition of medical care. It is clear, however, that definitions made by the ECJ and the wording of the Swedish legislation are relatively vague. The wording of the Swedish legislation does not contradict the clarifications made by the Court regarding therapeutic purpose, prevention.

The VAT Act may indeed be interpreted and applied in accordance with ECJ case law with regard to the medicalcare concept. Nor does the Swedish definition introduce elements that may be regarded as a deviation in relation to EU law with respect to the medical-care concept. Consequently, there is every reason to believe that the medicalcare concept of EU law can be properly implemented in Swedish tax law.

Nevertheless, the wording of the VAT Act may be suspected of counteracting a correct understanding of EU law, in that it uses a different terminology and does not separate what is stated in Art. 132.1 point $b$ and point $c$ of the Directive. The concept of medical care has been defined in the ECJ's practice. A special Swedish definition cannot change this. In my opinion, it would have been better, therefore, if the wording of the Directive was used in the VAT Act, possibly with the addition of one or more of the specifying formulations that the ECJ has made in its case law.

\subsubsection{Statements about the medical-care concept in preparatory works}

Swedish preparatory works such as Government bills include extensive motivations and explanations to the legislation proposals presented by Government to Parliament. They constitute an important source of Swedish tax law. The importance and assessment of this legal source has

58 A more detailed analysis, providing more room for the preparatory works, case law, and statements from the tax administration, can be found in my monograph on VAT-free health care (Påhlsson (2015). 
been modified, however, since Sweden's entry into the EU. Evidently, this was necessary because of the superiority of EU law.

In view of EU law taking precedence over national law, it is clear that the source value of the Swedish preparatory works must be put to question. Such statements relating to the autonomous concepts of EU law, such as the concept of medical care under Art. 132.1, have limited value. The Swedish legislature simply lacks the right to extend or restrict the scope of the concept in relation to its established EU law meaning (Rendahl (2015)).

It may be considered, however, that the EC)'s conceptual specifications lack sufficient precision. To the extent that EU law cannot be applied to concrete cases without interpretation, suggestions made by the national legislature may enhance consistency. With regard to the medicalcare concept, the statements made in Swedish preparatory works do not contradict proper application of the medicalcare concept as specified by the ECJ; nor do these works introduce elements strange to the proper application ${ }^{59}$.

\subsubsection{The Supreme Administrative Court's practice regarding the medical-care concept}

The Supreme Administrative Court (SAC) has explicitly addressed the scope and implications of the medicalcare concept in at least three cases ${ }^{60}$. It would seem that Swedish case law, represented in these cases, is compatible with the ECJ's practice.

One can never be certain, however, that the ECJ would approve of an assessment in casu, such as the one made by the SAC in RÅ 2003 ref. 5, in which qi gong practices were not deemed to fall within the medical-care concept ${ }^{61}$. It is possible, of course, that the ECJ would come to a different conclusion were it to try this particular activity.

Notably, the SAC seems to have misunderstood the scope of Art. 132.1 b when trying this case. After having discarded qi gong as not falling within the concept of medical

59 Statements on the medical-care concept are found mainly in Proposition (Prop.) 1993/94:99 and 2005/06:43 (Swed. Government bills).

60 See RÅ 2001 not. 40, RÅ 2003 ref.5 and HFD 2013 ref. 67 (Swed.). 61 Obviously, the Swedish courts cannot ask the ECJ for rulings about everything. For practical reasons, they must be prepared to interpret EU law and subsequently make their own assessments. The limited propensity of asking for preliminary rulings on Swedish law can be put to question, but the number of questions from Sweden is probably not remarkably low. This fundamental discussion is beyond the scope of this paper, however. care, the court went on to analyze the relationship between this activity and medical care. The qi gong services were supplied at a clinic falling within the scope of Art. 132.1 c, however, and not Art. 132.1 b.

Under the interpretation of the Directive delivered by the ECJ in C-366/12, Klinikum Dortmund supplies that are closely related to medical care are tax exempt only when related to medical care falling within the scope of Art. 132.1 b. Consequently, the test made in RÅ 2003 ref. 5 was pointless, given that supplies closely related to medical care under Art. 132.1 c are not tax exempt.

The SAC cannot, with reasonable reliability, be said to make extensions in relation to the interpretation of the medical-care concept made by the ECJ ${ }^{62}$. Perhaps one can trace a restrictive attitude of which it can be said that it is not obviously supported in ECJ practice. To further elaborate on this issue, however, would be pure speculation.

\subsubsection{Transactions closely related to medical care under the VAT Act}

In the same way as with the medical-care concept, the Swedish legislature has chosen to implement the condition closely related to its own terminology. The current wording of Ch. 3 Art. 4 of the VAT Act reads (my translation and emphasis added): "Exempt from tax are sales of services that constitute medical care, dental care, or social care and other kinds of services and goods supplied as part of the care" 63 .

The key phrase is supplied as "part of the care" (ett led $i$ vården), which, for some reason, is replacing "closely related" (nära knutna till vården). It is clear that the wording of the VAT Act sufficiently covers both the Directive's wording closely related, as well as phenomena which per se are part of medical care. Against this background, it can be concluded that the Swedish legislation allows for a correct implementation of EU law.

From a linguistic point of view, of course, it is also possible to give the wording of the VAT Act a broader interpretation. Under EU law, this would not be allowed, although problems arise on account of the VAT Act also containing its own definition of medical care in Ch. 3. Art. 5, which provides (my translation):

62 Qi gong was not deemed a closely related activity in the case RÅ 2003 ref. 5 (Swed.).

63 Emphasis added. 
By medical care is meant measures for the medical prevention, investigation, or treatment of diseases, physical defects and injuries, and care at childbirth,

- if the measures are taken in a hospital or in any other institution run by the public; or, in private activity, at institutions for patient care; or

- if the measures are otherwise taken by someone with special identification to practice a profession in medical care.

The formulation as part of the care in Art. 4 cannot be read in any way other than that it relates to the whole of the text of Art. 5 quoted in Section 4.1. This means that the element that corresponds to the Directive's closely related in the Swedish text has come to cover all the tax-exempt medical care, including such medical care that is tax exempt only under Art. 132.1 c of the Directive.

As mentioned in Section 3.7.3, the ECJ has in C-353/85 Commission v United Kingdom and recently in C-366/12 Klinikum Dortmund made it clear that the requirement closely related only covers the care that is tax exempt under Art. $132.1 \mathrm{~b}$. Consequently, the conclusion must be that the Swedish implementation has become too extensive.

What will be the result, then, if the Swedish legislation is tried against EU law in this regard? The answer must depend on whether the Directive is given direct effect in individual cases. Suppose certain private practitioners are engaged in medical care that is exempt from tax under Art. $132.1 \mathrm{c}$. If it is preferable for them to receive tax exemption for certain ancillary services or goods-in order to be able to deduct input tax, for example-and they do not want their supply to fall under the condition closely related, an invoking of the direct effect would mean overriding the VAT Act. If they were to claim exemption under the VAT Act, however, the issue would be if this law, in spite of the wording problems, can be interpreted in conformity with the Directive in such a way that closely related supplies that would have been tax free at a hospital become taxable for private practitioners.

In order to achieve an interpretation in conformity with EU law, it is necessary that as part of the care can be considered to cover the first leg of Ch. 3. Art. 5 only. I cannot see any other interpretation but that it is directly contrary to the wording. It will thus come in conflict with the principle of legality. The requirement of EU law conformity does not extend that far ${ }^{64}$.

64 See C-14/83 ECLI:EU:C:1984:153 von Colson och C-106/89 ECLI:EU:C:1990:395 Marleasing.
To summarize, the wording of Ch. 3 Art. 4 and 5 of the VAT Act allows for full application of EU law. Yet the Swedish wording extends the tax exemption to a larger area than that conferred by the Directive. Because the problem cannot always be solved with conforming interpretation, the Swedish law should be changed.

\subsubsection{Statements about the prerequisite closely related in preparatory works}

Swedish preparatory works hold only a few explanations and comments on the condition closely related. Nothing that is said appears to prevent EU law from being fully applied. But in addition, the preparatory works also seem to convey the conception that certain goods, such as hearing aids, which would otherwise be taxed, are tax exempt when supplied by a provider of medical care ${ }^{65}$.

This conclusion of the preparatory works is not in line with the practice of the ECJ. As concluded under Section 3.7.3, it is a prerequisite that a transaction be subordinate to the primary health-care transaction for it to be deemed closely related to it. In EU VAT law, a service is regarded as ancillary to a principal service if the customers do not ask for it specifically, but that it is only a means to the enjoyment of the actual service supplied ${ }^{66}$.

With regard to the ECJ's statement, the conclusion of the preparatory works' seems to suggest a broader view of tax exemption than is supported by the ECJ's practice. It is unlikely that hearing aids are tax free, for example, to the extent expressed in the motives statements. A patient may, of course, see a physician with the purpose of procuring a hearing aid; then the purchased hearing aid can hardly be seen as ancillary.

\subsubsection{The Supreme Administrative Court's practice regarding the prerequisite closely related}

The SAC has elaborated on the scope of the prerequisite closely related in at least two of its decisions ${ }^{67}$. It would appear that Swedish case law applies EU law to its full extent. However, case RÅ 2003 ref. 5 seems to allow tax exemption for supplies that are closely related to medical care that

65 See Proposition (Prop.) 2005/06:43 p. 54 and 58 (Swed.). 66 See C-349/96 Card Protection Plan para. 30. Also C-45/01 Dornier p. 33. The Court elaborates further in C-394/04 and C-395/04 Ygeia para. 20-30. 67 See RÅ 1997 not. 71 and RÅ 2003 ref. 5 (Swed.). 
falls under Art. $132.1 \mathrm{c}$. As discussed in Section 4.3.3, this is not in line with the e contrario interpretation made by the ECJ in C-366/12 Klinikum Dortmund.

\subsubsection{The duly recognized establishments of a similar nature under the VAT Act}

Medical care provided by "duly recognized establishments of a similar nature" is exempted from tax in Art. $132.1 \mathrm{~b}^{68}$. This provision has been implemented in Ch. 3 Art. 5 para. 1, first leg of the VAT Act, which states:

By medical care is meant measures for the medical prevention, investigation or treatment of diseases, physical defects and injuries, and care at childbirth,

- if the measures are taken in a hospital or in any other institution run by the public; or, in private activity, at institutions for patient care; or

- if the measures are otherwise taken by someone with special identification to practice a profession in medical care.

The condition for a private law body to qualify as a provider of medical care is that its supplies are to be delivered within an institution for patient care. The concept of patient care has been taken from other Swedish statutory law ${ }^{69}$.

It can hardly be claimed that there is care of this kind that would not be covered by Art. $132.1 \mathrm{~b}$ if the ECJ would examine that question. If there is "something wrong" with the Swedish regulation, therefore, it is that it is not comprehensive enough.

Nevertheless, it can be concluded that a distinction based on the Swedish patient-care criterion has not been considered by the ECJ. The Court's practice that allows some public funding requirements and probably some type of authorization requirement neither contradicts nor confirms the Swedish legislation's compatibility with the Directive. In addition, the conditions under which Member

68 Point b reads in full: "hospital and medical care and closely related activities undertaken by bodies governed by public law or, under social conditions comparable with those applicable to bodies governed by public law, by hospitals, centres for medical treatment or diagnosis and other duly recognised establishments of a similar nature".

69 See Hälso- och sjukvårdslagen (1982:763) (Health Care Act) Art. 5 para. 1, according to which opportunities for insertion/overnight stay for patients is a necessary condition for the concept of patient care. In addition, see Prop. 2005/06:43 para. $46 \mathrm{f}$.
States, according to Art. 133 of the Directive, may impose profit restrictions, for example, does not mention patient care of the type defined in Swedish law. Art. 133 is not exhaustive, however. Thus, it is permissible, in principle, to impose conditions other than those contained therein.

In conclusion, it is unclear whether the Swedish condition patient care is compatible with EU law. I believe that the Swedish legislation is fully acceptable. It enables a correct implementation of the Directive, and it does not add anything beyond that.

\subsubsection{The concept of medical care under Art. $132.1 \mathrm{c}$ as implemented by the VAT Act and its preparatory works}

The analysis of ECJ case law in Section 3.7.5 has shown that the same concept of medical care is used in Art. $132.1 \mathrm{~b}$ and c. The therapeutic purpose allowing for prevention measures has been specified in a number of cases. There are, however, two differences with regard to medical care under point b and c, respectively, the place of supply and the demands placed on the providers. In addition, the transactions closely related to medical care are tax free under Art. $132.1 \mathrm{~b}$ only.

As mentioned in Section 4.1, the Swedish VAT Act contains its own definition of medical care. Unnecessarily, this gives the Swedish courts, tax administration, and tax subjects two definitions to relate to-one formulated by the ECJ and the other formulated in VAT Act. The evaluation and weighing of the information provided in the sources of law is thereby obscured. A clear example of the consequences is that the ECJ's well-chiseled definition of medical care is presented by the Swedish legislature as part of the Swedish tax administration's own assessment! ${ }^{70}$ Apart from this, as far as I can see, the relatively detailed statements in preparatory law constitute a correct description of how the ECJ defines medical care.

Thus, it can be concluded that the VAT Act and its preparatory works enable a correct application of the medical-care concept in the VAT Directive as interpreted by the ECJ. The Swedish legal sources do not add anything beyond EU law in this regard. It can hardly be claimed, however, that the VAT Act and the preparatory works facilitate the application of EU law by bringing forth their own medical-care definition.

70 This strange and misleading reference is found in Prop. 2005/06:43 s. 46. 


\subsubsection{The concept of medical care under Art. $132.1 \mathrm{c}$ in the Supreme Administrative Court's practice}

In several decisions, the SAC has had to examine whether the supplies have been within the framework of the European Union's law of medical care under point c of Art. $132.1^{71}$. It should be noted that the SAC has chosen not to distinguish between care under Art. $132.1 \mathrm{~b}$ and care in accordance with Art. $132.1 \mathrm{c}$. Instead, the Court's reasoning is completely based on the construction of the VAT Act, which, as previously mentioned, contains its own definition.

In conclusion, the SAC's practice complies with the ECJ's with respect to the requirements of medical care. There is some ambiguity, however, regarding the rulings on care supplied on the Internet. The SAC seems to have categorically held that medical advice supplied on the Internet could not qualify as medical care. It is not unlikely that this position would be upheld, where the ECJ to analyze the issue. One cannot be sure, however; and given the rapid development of Internet care in northern parts of Sweden, with its scarce population and long distances between populations, it appears possible that a different conclusion could be argued ${ }^{72}$.

\subsubsection{Medical and paramedical professions as defined in Swedish law}

The provision in Art. $132.1 \mathrm{c}$ of the VAT Directive, delegating the right of Member States to define the relevant professions, reads: "the provision of medical care in the exercise of the medical and paramedical professions as defined by the Member State concerned"; In Ch. 3 Art. 5 of the VAT Act, Swedish law recognizes the relevant categories with the wording "If the measures are otherwise taken by someone with special identification to practice a profession in medical care."

The special identifications given in the Patient Safety Act (2010:659) covers a range of what is generally considered paramedical professions. It seems clear that the Swedish VAT Act's requirements are compatible with EU law in this respect. In remains to be investigated, however,

71 See, for example, RÅ 2003 ref. 5 (qi gong) and RÅ 2007 ref. 88 (two decisions regarding internet supplies) (Swed.).

72 Moreover, it appears that the double medical-care definitions in both EU law and in the VAT Act led the SAC at one point to try wrongly the requirement closely related in relation to Art. 132.1 c. See Section 4.3.6. whether any statements in the additional Swedish legal sources are apt to implement EU law properly, as explained by the ECJ.

\subsubsection{Statements on medical and paramedical professions in preparatory works}

In the motivations to legislative amendments that defined the four categories of audiologists, dieticians, medical technologists, and orthopedic engineers as paramedical professions, the legislature conducted a discussion on the VAT consequences of the new rules ${ }^{73}$. The reasoning in the bill assumes that an audiologist with sales of hearing screening and hearing-aid equipment is tax exempted for both supplies. According to the Government, the hearing aid is closely related to medical care. Yet for goods to be exempt because they are closely linked to medical care, it is necessary that they be provided in hospitals or similar institutions-that they fall under Art. $132.1 \mathrm{~b}$. Under these circumstances, the profession identification issue is not relevant. As I understand it, the bill mixes apples and oranges. It is extremely doubtful whether hearing aids meet the requirement to be subordinate, such that they be regarded as closely related under the ECJ's practice. On the contrary, they should probably be seen, in most cases, as an end in themselves for the health-care consumer. Under such circumstances, they are not tax exempt. Other than in hospitals and the like (e.g., the audiologists whose paramedical identity was introduced by the bill), hearing aids are never exempt because they are not part of medical care per se. As mentioned, the prerequisite closely related does not apply to supplies that fall under Art. $132.1 \mathrm{c}$. The conclusion is that the reasoning in the bill on tax exemption for audiologists is not supported in EU law.

\section{Conclusion}

The purpose of this paper was to determine how the VAT exemption for medical care was identified in European Union law and in Swedish national law. Conclusions have been drawn throughout, so only a few brief reflections will be made here.

Most of the key constituent elements of the VAT Directive exception-the concept of medical care and services closely linked to medical care-are EU law concepts whose

73 See Prop. 2005/06:43. 
meaning the ECJ has specified in more than a dozen cases. For care at hospitals and elsewhere, however, the Member States have significant room for maneuvering because they can trigger tax exemption by opting to recognize different health facilities and by legitimizing medical and paramedical professions.

Therein lies a paradox. For although the medical-care concept is harmonized, its relevance is dependent on the way the Member States use the Directive's delegation. There is certainly a common meaning for the concepts. But their legal significance is strongly affected by the way the Member States exercise the control space delegated to them. The harmonization of the medical exemption appears against this background to be at least partly illusory.

Neutrality and equal treatment are assumed to be fundamental to the VAT system. The medical-care exception is also an exception from these two fundamental principles, by breaking out and giving special treatment to certain supplies made by certain operators. This fundamental observation was mitigated somewhat, however, when the ECJ chose to fall back on neutrality and equal treatment in several cases.

Private actors' forms of organization are protected by EU law, in that Member States cannot normally provide that certain legal forms must be used. Art. 133 of the Directive allows for far-reaching restrictions on tax exemption, however, based, among other things, on profit limitations and the identification possibilities.

The Swedish implementation seems undeniably ambivalent. Although the medical-care concept is assumed to be part of EU law and has been specified by the ECJ, Sweden persists in its own definition, which, for historical reasons, is based on the wording in other legislation. This does not prevent a correct implementation of EU law, but neither does it make things easier. It simply becomes a double regulation. This is unnecessary, and the Directive should rather be introduced in Swedish legislation, possibly with some clarification.

Furthermore, a consequence of the technical solutions used in the Swedish VAT Act is that the tax exemption is extended beyond what follows from the ECJ's practice, in terms of what should be considered closely related to medical care. This is a deficiency that should be remedied through legislation. There are more problems with the Swedish implementation of the health exception, but they are of minor importance.

For private parties, this lack could result in a more comprehensive tax exemption than intended. This comprehensive exemption is offset to some extent by the fact that the SAC appears to have regarded it as their task to ob- serve restrictivity when applying the medical-care exemption.

\section{References}

Agrell, Joachim and Ericsson, Helena. 2008. Regeringsrättens dom om mervärdesskatteplikt vid läkarkonsultationer via internet. Skattenytt (1): 205-9.

Alhager, Eleonor. Mervärdesskatt vid omstruktureringar. Uppsala 2001: lustus Förlag.

Aujean, Michel, Jenkins, Peter \& Poddar, Satya. 1999. A new approach to public sector bodies. VAT Monitor, (4): 144-9.

Confederation of Swedish Enterprise. (2015). http://www.svensktnaringsliv.se/material/skrivelser/oversynav-befintlig-lagstiftning-om-mervardeskatt-for-offentliga_ 587686.html Accessed 8 October 2015.

Confederation of Swedish Enterprise. (2015). http://www.svensktnaringsliv.se/material/remissvar/gronbokom-mervardesskattens-framtid-green-paper-on-the-futureof_564432.html Accessed 8 October 2015.

Eskildsen, Casper Bjerregaard. Strukturneutralitet i momssystemet. Aarhus 2012: Business and Social Sciences, Aarhus University.

European Commission. (2011). Consultation Paper - Review of existing VAT legislation on public bodies and tax exemptions in the public interest. $\mathrm{COM}(2011) 851$ final.

European Commission. (2010).Green Paper on the future of VAT: towards a simpler, more robust and efficient VAT system. (COM(2010)695) final.

de la Feria, Rita. 2009. The EU VAT treatment of public sector bodies: slowly moving in the wrong direction. Intertax. Vol. 37 (3): 148-65.

de la Feria, Rita. 2010. Future Health Technologies. VAT Exemption. Highlights and Insights of European Taxation (10): 130-3.

Henkow, Oskar. Financial Activities in European VAT. Lund 2008: Kluwer Law International.

Henkow, Oskar. The VAT/GST Treatment of Public Bodies. Lund 2013: Kluwer Law International.

Hultqvist, Anders. Moms och finansiella tjänster. Stockholm 1998: Norstedts Juridik.

Hölzer, Camilla. 2010. Rechtsprechung - Steuerbefreiungen bei Lieferungen und sonstigen Leistungen, UmzatzsteuerRundschau (14): 526-40.

Janssen, Sjoerd. 2008. CopyGene. VAT Exemption. Highlights and Insights on European Taxation (9): 99-101.

Jepsen, Anders Strandet. Moms og aktiviteter i forbindelse med vaerdipapirer. Köpenhamn 2010: Thomson Reuters.

Jespersen. Claus Bohn, Intermediation and insurance and financial services in the European VAT. Köpenhamn 2011: Kluwer Law International.

Lundström, Susann. 2004. EG-aktuellt på mervärdesskatteområdet. Begreppen sjukvård och sjukvårdande behandling. Svensk skattetidning: 50-2.

Melz, Peter. Mervärdesskatten. Rättsliga grunder och problem. Stockholm 1990: Juristförlaget.

Niedermair, Jutta. 2006. Keine Befreiung von der MwSt fur Leistungen im Zusammenhang mit einem Krankenhausnebenleistungen. European Law Reporter (3) 127-9. 
Nieskens, Hans. 2006. Umsatzsteuerfreiheit fur Krankenhausnebenleistungen. EU-Umsatzsteuer-Berater (3): 35-6.

Novak-Stief, Monika. 1999. Steuerbefreite Umsätze von Kranke - und Pflegeanstalten. European Law Reporter (10): 432-5.

Påhlsson, Robert. (2015). Momsfri sjukvård. Uppsala 2015: Iustus Förlag.

Rasmussen, Karin Schwarz Revsbeck. Momsfritagelsen af transaktioner inden for sundhetsområdet - i et EU-retligt og nationalt perspektiv. Köpenhamn 2013: DJÖF Förlag.

Ramsdahl Jensen, Dennis. Mervaerdiafgiftspligten. Köpenhamn 2004: DJÖF Förlag.

Rendahl, Pernilla. Cross-Border Consumption Taxation of Digital Supplies. Amsterdam 2009: IBFD.

Rendahl, Pernilla. (2015). Rapport: Mervärdesskattelagens ändamål - En konsumtionsskatt och en företagsskatt. Stockholm 2015: Confederation of Swedish Enterprise (Svenskt Näringsliv).

Skatteverket (SKV, the Swedish tax administration). (2015). http://www.skatteverket.se/foretagorganisationer/moms/ momsforstatkommun/momsersattningtillkommuner.4. 18e1b10334ebe8bc80005490.html Accessed 8 October 2015.
Sonnerby, Mikaela. Neutral uttagsbeskattning på mervärdesskatteområdet. Stockholm 2010: Norstedts Juridik.

Stensgaard, Henrik. Fradragsret for mervaerdiafgift. Köpenhamn 2004: DJÖF Förlag.

Swinkels, Joep. 2005. VAT Exemption for Medical Care, VAT Monitor (1): $14-8$.

Theile, Carsten. 1995. Wettbewerbsneutralität der harmonisierten Umsatzsteuer. Theoretischer Anspruch und praktische Umsetzung. Köln: Otto Schmidt.

Vårdföretagarna (2015). http://www.vardforetagarna.se/fakta-ochdebatt/fakta-statistik Accessed 8 October 2015.

Westberg, Björn. 2009. Kommentar till mervärdesskattedirektivet. Stockholm: Thomson Reuters.

Westberg, Björn. 1994. Nordisk mervärdesskatterätt. Stockholm: Juristförlaget.

Öberg, Jesper. 2001. Mervärdesbeskattning vid obestånd. Stockholm: Norstedts Juridik. 